\title{
GEO-ENVIRONMENTAL CHANGES AND HISTORICAL EVENTS IN THE AREA OF THE GREEK ARCHAEOLOGICAL SITE OF SELINUNTE (WESTERN SICILY, ITALY)
}

\author{
Margherita Bufalini ${ }^{1}$ \\ Domenico Aringoli ${ }^{2}$ \\ Petros Didaskalou ${ }^{3}$ \\ Marco Materazzi ${ }^{4}$ \\ Fabio Pallotta ${ }^{5}$ \\ Gilberto Pambianchi ${ }^{6}$ \\ Pietro Paolo Pierantoni ${ }^{7}$
}

Recebido em: 30/11/2021 Aprovado em: 20/12/2021

\begin{abstract}
Detailed geomorphological and geo-archaeological surveys were carried out in this study at the Greek archaeological site of Selinunte to reconstruct the landscape evolution that occurred before and during the anthropization of the site and to verify the possible correlations between geo-environmental changes and human events that characterized almost four centuries of the history of the city. By using a multidisciplinary approach and different survey techniques, this study testified the role played by climate, geomorphological setting and georesources in conditioning the development of the city and the close relationship sometimes observed between the historical events and natural processes. This included the controversial and never discovered hydraulic work of Empedocles who, according to textual sources, in $444 \mathrm{BC}$, resolved a public health problem linked to the presence of marshy areas.
\end{abstract}

Keywords: Selinunte; Geo-archaeology; Climate change; Societal changes; Empedocle's work.

\footnotetext{
${ }^{1} \mathrm{PhD}$ in Applied Geomorphology at the University of Camerino (UNICAM). Post-Doctorate researcher at School of Sciences and Technologies Geology Division, UNICAM, Italy. E-mail: margherita.bufalini@unicam.it. Orcid: https://orcid.org/0000-0003-3278-7058.

${ }^{2} \mathrm{PhD}$ in Applied Geology, Geomorphology and Hydrogeology at the University of Perugia. Researcher (administrative technical staff) at School of Sciences and Technologies - Geology Division, UNICAM, Italy. Email: domenico.aringoli@unicam.it. Orcid: https://orcid.org/0000-0001-8365-9705.

${ }^{3}$ Researcher (administrative technical staff) at School of Sciences and Technologies - Geology Division, UNICAM, Italy. E-mail: petros.didaskalou@unicam.it.

${ }^{4}$ Associate Professor of Geomorphology and Hydrogeology at School of Sciences and Technologies - Geology Division, UNICAM, Italy. E-mail: marco.materazzi@ unicam.it. Orcid: https://orcid.org/0000-0002-9480-5680.

5 Geologist and Geoarchaeologist, freelance - Via Lorenzoni 7, Macerata 62100, Italy. E-mail: geologopallotta@gmail.com.

${ }^{6}$ Full Professor Lecturer of Geomorphology and Environmental Geology at School of Sciences and Technologies - Geology Division, UNICAM, Italy. E-mail: gilberto.pambianchi@unicam.it. Orcid: https://orcid.org/00000001-7347-7721.

${ }^{7} \mathrm{PhD}$ in Geology at UNICAM. Researcher, Professor of Structural Geology at School of Sciences and Technologies - Geology Division, UNICAM, Italy. E-mail: pietropaolo.pierantoni@unicam.it. Orcid: https://orcid.org/0000-0002-1237-4689.
} 


\section{MUDANÇAS GEOAMBIENTAIS E EVENTOS HISTÓRICOS NA ÁREA DO SÍTIO ARQUEOLÓGICO GREGO DE SELINÔNTE (SICÍLIA OCIDENTAL, ITÁLIA)}

Resumo: Neste estudo no sítio arqueológico grego de Selinônte foram realizados levantamentos geomorfológicos e geoarqueológicos detalhados com o intuito de reconstruir a evolução da paisagem que ocorreu antes e durante a antropização do sítio e para verificar as possíveis correlações entre mudanças geoambientais e eventos humanos que caracterizou quase quatro séculos da história da cidade. Utilizando uma abordagem multidisciplinar e diferentes técnicas de levantamento, este estudo testemunhou o papel desempenhado pelo clima, configuração geomorfológica e georrecursos no condicionamento do desenvolvimento da cidade e a estreita relação por vezes observada entre os acontecimentos históricos e os processos naturais. Isso incluiu a polêmica e nunca descoberta obra hidráulica de Empédocles, que em 444 a.C., conforme as fontes textuais, resolveu um problema de saúde pública ligado à presença de áreas pantanosas.

Palavras-chave: Selinônte; Geoarqueologia; Mudanças climáticas; Mudanças sociais; Obras de Empédocles.

\section{CAMBIOS GEOAMBIENTALES Y EVENTOS HISTÓRICOS EN EL ÁREA DEL SITIO ARQUEOLÓGICO GRIEGO DE SELINÔNTE (SICILIA OCCIDENTAL, ITALIA)}

Resumen: En este estudio en el sitio arqueológico griego de Selinônte, se llevaron a cabo estudios geomorfológicos y geoarqueológicos detallados con el fin de reconstruir la evolución del paisaje que ocurrió antes y durante la antropización del sitio y verificar posibles correlaciones entre cambios geoambientales y eventos humanos que caracterizó casi cuatro siglos de historia de la ciudad. Con un enfoque multidisciplinario y diferentes técnicas de levantamiento, este estudio fue testigo del papel que juega el clima, la configuración geomorfológica y los georrecursos en el condicionamiento del desarrollo de la ciudad y la estrecha relación que en ocasiones se observa entre hechos históricos y procesos naturales. Esto incluyó la controvertida y nunca descubierta obra hidráulica de Empédocles, quien en el 444 a. C., según fuentes textuales, resolvió un problema de salud pública vinculado a la presencia de zonas pantanosas.

Palabras clave: Selinunte; Geo-arqueología; Cambio climático; Cambios sociales; El trabajo de Empédocles.

\section{Introduction}

Modern paleoclimatological and geoarchaeological studies continue to add new data that increasingly establish the connection between climate change or natural disasters and the evolution of human societies. However, the role of climate change (or disasters like earthquakes and floods) in conditioning societal changes has been highly contested and can be mostly categorized as the struggle between "maximalism" and "minimalism" (Suhrke, 1993). The 
former idea views climate change as something that induces specific societal outcomes, such as conflicts (Burke et al., 2009) or migrations (Myers, 2002), while the minimalist "current" does not consider environmental changes as the main driver of social change or even considers it to have no significance (Jónsson, 2010).

However, it has been well-established that certain periods in the geological history, with global temperatures comparable with or greater than the present, predated the emergence of modern human beings (Huber, 1998; Bice and Norris, 2002; Haywood and Williams, 2005; Brooks, 2006 and 2012). Similarly, many studies have linked cold-arid phases with societal changes, including the collapse of Akkadian Empire around 4200 BP (Cullen et al., 2000), the end of Egyptian Old Kingdom (Stanley et al., 2003), the crises at the Neolithic sites in northcentral China (Wenxiang and Tungsheng, 2004; Chen et al., 2005) as well as the collapse of many other cultures and societies throughout the history due to prolonged periods of drought (Weiss and Bradley, 2001; DeMenocal, 2001; di Lernia, 2002: Brooks, 2010). Societal changes associated with natural events, despite being of lesser magnitude, were also recorded in wellstructured civilizations, such as the Roman Empire. A typical example is that of the Roman town of Carsulae in central Italy (Bottari et al., 2017), which was progressively abandoned owing to seismic events, periodic flooding and subsidence due to the presence of natural cavities (sinkholes).

This paper describes the results of the detailed survey carried out at Selinunte (SouthWest Sicily, Italy), an important Greek archaeological site and currently the largest archaeological park of Europe. In this study, geomorphological and geo-archaeological surveys, aerial images analyzed using UAVs (Unmanned Aerial Vehicles), paleoclimatic and palaeohydrological surveys, stratigraphic cores and Geographic Information Systems were used to highlight the close correlation between the climatic events and anthropization in the periods preceding and contemporary to the development of the city, which largely occurred between the VIth and the IVth centuries BC. In particular, the methods used established that the particular and favorable geological-climatic-environmental conditions were fundamental for the occupation of the site by the first Greek colonists. However, the same conditions, which progressively became less suitable, contributed, along with the adverse socio-political events, to the gradual decline of Selinunte.

Additionally, detailed investigations were carried out in the northern part of the site, which helped in formulating, possibly for the first time, a hypothesis on the existence and location of the historical hydraulic intervention created by Empedocles of Agrigento. According to historian Diogenes Laertius (VII, 2 70), in 444 BC, Empedocles ended the period 
of plagues and diseases, generated by the presence of swampy areas, by creating an important hydraulic structure; however, despite being often quoted by the historians and archeologists, no trace of it has been found till date.

\section{Regional setting and climatic factors}

The archaeological site of Selinunte (Fig.1a) can be divided into four broad areas (Fig.1b):

- the Eastern Hill, containing Temple G (temple of Zeus), one of the largest temples built by the Greeks in the Mediterranean, Temple E (temple of Hera), and Temple F (temple of Athena or Dionysus);

- the Acropolis, where the "Ippodameus" road system is still visible and the temples A, O, R, B, C (or temple of Apollo), D, and Y were situated;

- the Manuzza Hill, with the urban districts and Agorà;

- the final portion of the Modione River (the ancient $\Sigma \varepsilon \lambda$ ívov, after which the city was named) that is situated west of Acropolis and flows in north-south direction. In this sector, along the right river bank, the "extra-urban Sanctuaries" are situated: the Temple of Hera Matronale, the Sanctuary of Demetra Malophoros, the small temple of Zeus Meilichios, and the Temple M. 

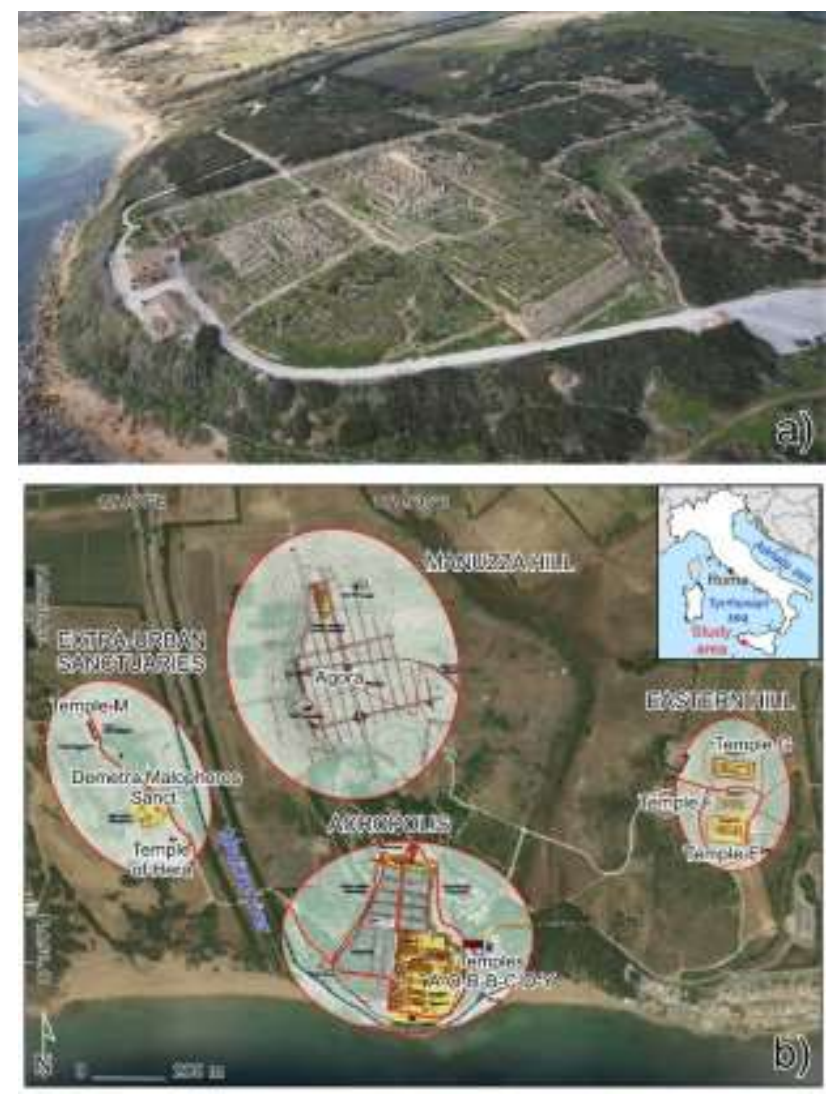

Figure 1 - a) Panoramic view of the Acropolis of Selinunte; b) the archaeological park of Selinunte: location of the main archaeological sectors.

The study area, located along the SW coastal belt of Sicily, is characterized by vast subflat areas, bordering the hills, with less than $20 \%$ slopes and altitudes ranging from 0 to $250 \mathrm{~m}$ a.s.l. in the innermost portions. The coastal plain is characterized by the presence of a series of marine terraces, which can be found up to a height of $170 \mathrm{~m}$ a.s.l. (D'Angelo and Vernuccio, 1996, Di Maggio et al., 2017). These landforms, sometimes covered by paleosoils, are easily recognizable due to the presence of numerous morphological steps. Basing on preliminary micropaleontological analyses carried out by the present authors on a sample of bedrock taken in the area of the acropolis (see Fig.2), the age of the top of the terrace in this area can be attributed to the end of the early Pleistocene; more specific investigations relating to these aspects, are currently underway.

Sandy-silty alluvial deposits, locally terraced, with ages ranging from late Pleistocene to Holocene, characterize the final sector of the main rivers (Modione and Belice), which have been artificially restricted and rectified today. The coastal area is instead characterized by wide, mainly sandy beaches, where coastal dunes, positioned parallel to the shoreline and wetlands, partially or totally dried up today and locally known as "Gorghi", are visible. Some of these 
("Preola lake" and "Gorghi Tondi") represent particularly sensitive ecosystems and are home to natural reserves (Fig.2).

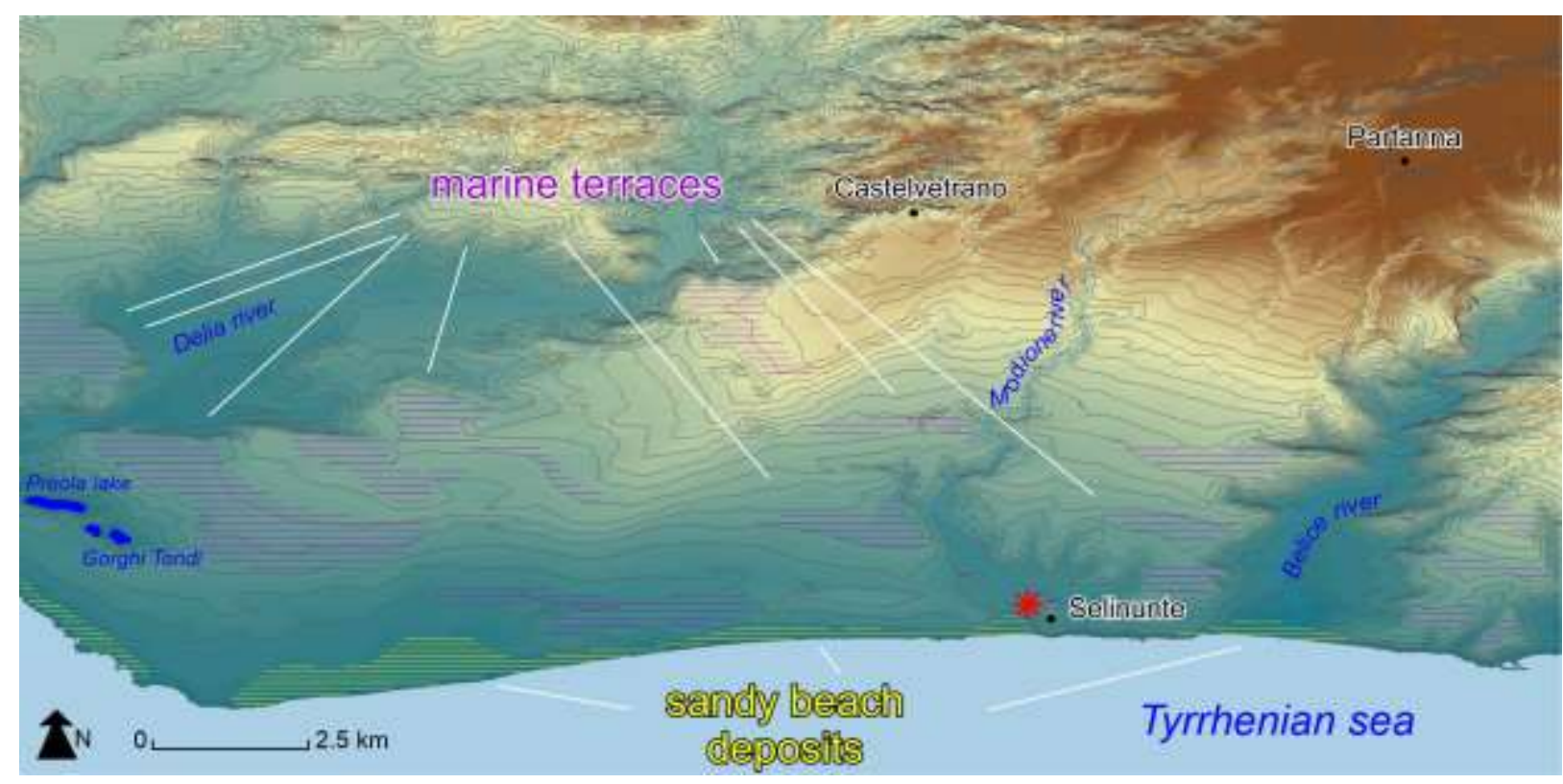

Figure 2 - Morphological sketch of the study area with indication of the main geomorphological features (the equidistance of the contour lines is $10 \mathrm{~m}$ ). Red asterisk indicates the location of the sampling point.

From a geological point of view (Fig.3), the stratigraphic succession, from the top downwards, is characterized by Quaternary marine deposits, consisting of sand and bioclastic limestones passing laterally and vertically to calcarenites and calcirudites (Ruggieri et al., 1977; D'Angelo and Vernuccio, 1994; Lentini and Carbone, 2014). These deposits lie with stratigraphic unconformity on the Marnoso-Arenacea formation of the Belice valley, which consist of a Plio-Quaternary terrigenous sequence (sandstones and calcarenites with clayey intercalations). More in depth, Pliocene calcilutitic marly deposits (the "Trubi") overly the Messinian evaporitic succession, made by evaporitic limestones and gypsum, with stratigraphic unconformity on the sandy-conglomeratic or on the clayey-marly deposits of the Cozzo Terravecchia Formation (Lentini and Carbone, 2014). 


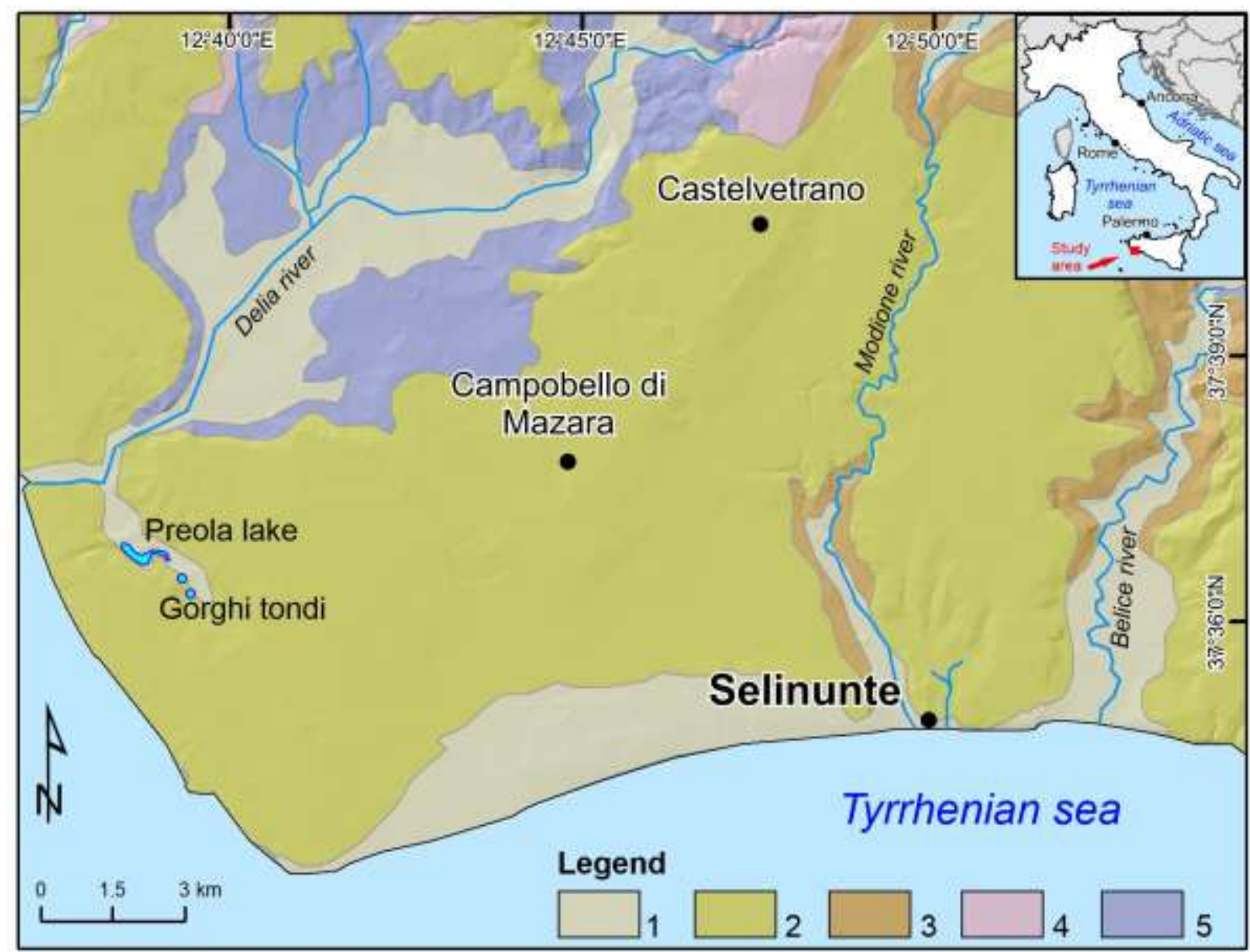

Figure 3 - Geological sketch of the study area: 1) Undifferentiated continental and marine deposits (Middle Pleistocene - Holocene); 2) Marine terrigenous deposits, calcarenites and clays (Late Pliocene - Middle Pleistocene); 3) Clayey-sandy-calcarenitic deposits (end of Early Pliocene - Late Pliocene); 4) Pre-evaporitic and evaporitic deposits (Late Messinian - Early Pliocene); 5) Clays, sands and conglomerates (Late Tortonian - Early Messinian).

All these deposits have been involved, since Messinian to Middle-Pliocene, by a compressive tectonic phase that generated a synclinal structure along the northeast-southwest direction with a gentle dip to SW. Finally, during Quaternary, evidences of a mainly extensional tectonic phase have been found within the post-Tyrrhenian deposits.

From a climatic point of view, the study area has a typical Mediterranean climate, with hot and dry summers and mild and moist winters. The mean annual air temperature at the nearby weather station in Mazara del Vallo (20 km east of Selinunte) was noted as $18.2{ }^{\circ} \mathrm{C}$, with the maximum being $26.3^{\circ} \mathrm{C}$ in August and the minimum being $11.4^{\circ} \mathrm{C}$ in January (Bonaccorso et al., 2003; Liuzzo et al., 2017). Precipitation was observed to be the highest during the fall and winter $(177 \mathrm{~mm})$, while significantly lesser precipitation was observed during the summer (16 $\mathrm{mm})$. 
Although the exact date of the foundation of Selinunte is still debated, ancient historians have agreed to place it in the second half of the VIIth century BC. The city was founded by Greek colonists from Megara Hyblaea (Thucydides-War, VI 14 ), one of the first Greek colonies of Sicily, located a few kilometers from Syracuse. In a short period, Selinunte experienced extraordinary growth. For example, despite being destroyed first by the Carthaginians in 409 BC and second by the Romans in 250 BC (Diodoro XIII, 59 4), it became the most important city of western Sicily and continued to be inhabited until around the XIIIth century BC. Owing to progressive abandonment, following this period, the ruins of the city were covered under thick, sandy aeolian sediments and dense coastal vegetation.

The name "Selinunte" originated from the Greek $\sigma \varepsilon \lambda$ ívov, which means vulgarly parsley or wild "appio," a plant typically found in wet areas. It is commonly found in Sicily and Sardinia (as well as in Greece and Anatolia) and abounds the terminal portions of the Selino River (known as the Modione River today) and Gorgo Cottone.

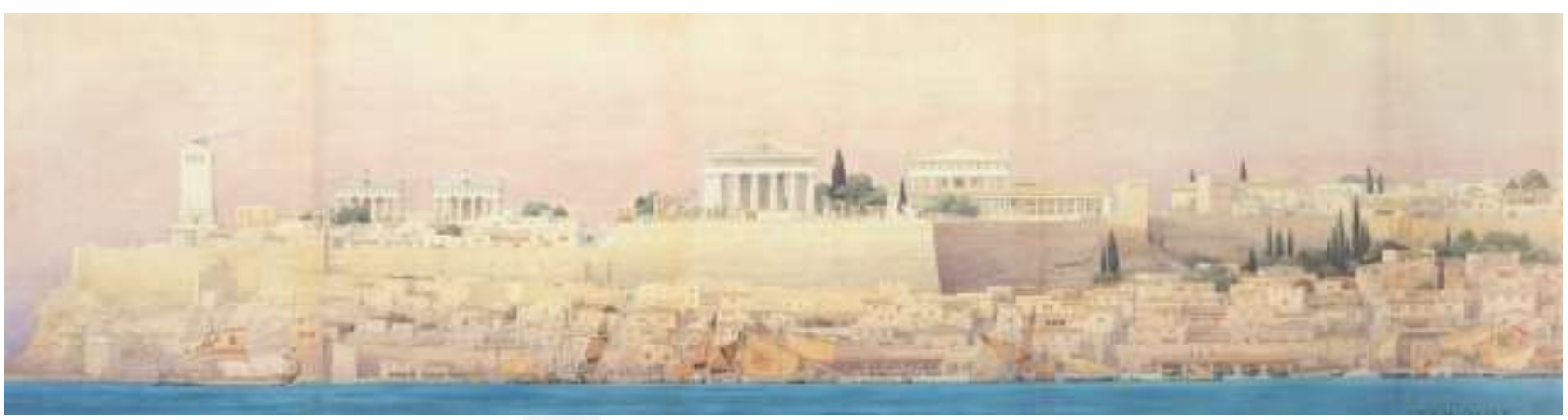

Figure 4 - Hypothesis of reconstruction of the city of Selinunte in the $\mathrm{V}^{\text {th }}$ century BC (modified from Hulot and Fougères, 1910)

During the first period of its history, between VIIth and Vth centuries BC, Selinunte experienced great progress (Fig.4), when its dominion was extended to the surrounding areas to secure more territories for cultivation as well as extending the area under its control. In fact, inhabitants of Selinunte extended their dominion to south east, until the present city of Sciacca and to the territory border of Agrigento, and to north-west, until the mouth of Mazaro River, where the city of Mazara del Vallo is situated and a trading port was created (emporion).

Less accurate and sometimes conflicting information is available for the period from the Vth century to $410 \mathrm{BC}$, when the city was the center of several conflicts. Due to mercantile reasons as well as due to its rivalry with Agrigento (who had taken the control of Eraclea Minoa) and Syracuse that had destroyed the motherland Megara Hyblaea, Selinunte took the side of 
Phoenicia in the conflict between Greeks and Phoenicians during the battle of Imera (480 BC) (Diodorus XIII, 59 4). Additionally, some historical sources have also reported conflicts with the nearby city of Segesta (in 454, 416, and 410 BC); however, many historians do not agree on the occurrence or consistency of these events.

The hydraulic intervention conceived by Empedocles, dated by historian Diogenes Laerzio (VII, 2 70) as 444 BC, is an important climatic and sociological episode in the history of Selinunte. Selinunte was at that time affected by a serious "public health" problem, due to the presence of swampy areas that generated plagues and diseases. Empedocles, a philosopher, politician, doctor, and engineer, who lived in the Vth century BC, was asked by the inhabitants of Selinunte to reclaim the site. Subsequently, he succeeded in reclaiming the site by implementing an ambitious hydraulic project to channel the nearby "two rivers" and thus, eliminating the problem of swamping.

The first real "collapse" of the city took place in 409 BC when Annibale Magone reached Lilibeo, in SW Sicily, with an imposing army and after being joined by the allies from Segesta and other cities, he attacked Selinunte and destroyed it after only nine days of the siege (Diodorus, XIII, 54-59). The reconstruction of the subsequent phase is mostly unclear, because the historical datum does not often coincide with the archaeological evidence. Diodorus (XIII, 44 3) reported that between 409 and 408 BC, Hermocrates from Syracuse came to the aid of Selinunte, defeated the Carthaginians, and succeeded in raising the city walls. The period after this was marked by a succession of treaties signed between Syracuse and Carthage; however, very few archeological evidences have been found to corroborate this. Nevertheless, the increasingly closer relationship between Carthage and Selinunte, alternated by conflicts and commercial agreements, characterized most of the IVth century BC.

The irruption of the overbearing competition from Rome on the maritime routes from the beginning of the IIIrd century BC led to the second destruction of Selinunte (in $250 \mathrm{BC}$ ). By losing the balance between the cities and people that hitherto ruled the places, Rome managed to take over the territory of the Carthaginian epicracy, within a few decades.

\section{Data and discussion}

In this study, the relationship between historical events occurred between 2700 and 2220 yrs BP (sometimes not consistently described by historians of the period) and natural processes, controlled by climate change, has been defined by carrying out a series of investigations (both 
in field and laboratory), repeated over time and conducted using a multidisciplinary and iterative approach. Summaries of the methods used are mentioned below.

- Detailed geological and geomorphological surveys (at a scale of 1:1000 or higher) to recognize past and present landforms, deposits and processes.

- Aerial images acquired through UAVs and photointerpreted for recognizing and correlating complex geomorphological landforms.

- Specific hydrological and hydrogeological surveys for reconstructing the changes observed in the hydrological regime of rivers and springs.

- Geophysical prospecting (2D Electrical Resistivity Tomography) for conducting noninvasive study of the stratigraphy of some key sectors of the study area.

- Geognostic boreholes, carried out in specific areas, for correctly reconstructing the stratigraphy and collecting samples for laboratory analysis.

Results of these investigations are presented below vis-à-vis the known evolution of historical and social context, which was divided into two main phases in this study. The first phase corresponded to the ancient phase, preceding the foundation of the city and up until the Holocene "climatic optimum," when the main physical landscape elements have been defined. The second phase corresponded to the period of maximum development in the city until its decline and subsequent Roman occupation around 2200 yrs BP.

\section{Geomorphological changes and historical events between 7000 and 2200 yrs B.P.}

\section{Ancient phase (7000-2600 yrs B.P.)}

With regard to natural landscape, the historical starting point shows that when Selinunte was founded by the first Greek colonists from Megara Hyblaea (assumed to have happened around $2700 \mathrm{yrs}$ BP) and for several centuries that followed, the configuration of the coastal belt was significantly different compared to that of current period. At that time, the geomorphological and hydrogeological conditions of Selinunte were significantly similar to the places of origin of its colonists, who came from the eastern coast of Sicily, situated north of Syracuse, and found a territory with analogous conditions.

Numerous historical sources verify that the promontory on which the Acropolis of Selinunte stood was situated between two gulfs of moderate sizes to its east and west, which extended inward a few hundred meters and were used as military and commercial ports for several centuries. 
The historical data is congruent with the climatic events and geomorphological processes that until then depended on the evolution of the coastal landscape of SW Sicily. In fact, the entire area (similar to the coastal belt of entire Mediterranean basin) was still affected by the effects of the Flandrian transgression, when the sea level reached its maximum around 7000 yrs BP and gradually stabilized close to the current values around 4500 yrs BP (Lamb, 1995; Antonioli et al., 2002; Lambeck et al., 2004 and 2011). In this context, the mouths of the major rivers showed relatively large and significantly deep inlets, to be navigable for several kilometers inland (Vita-Finzi, 1969; Delano-Smith, 1979, Zazo et al., 2008).

The possibility of the existence of this context was verified by conducting field surveys at the mouths of the Modione and Gorgo Cottone (situated east of the Acropolis of Selinunte) rivers. The results were processed using GIS, where a detailed Digital Terrain Model, with $2 \mathrm{~m}$ pixel resolution derived from LIDAR (Light Detection And Ranging) survey provided by the Italian Ministry of the Environment, was built.

For reconstructing the topographical setting of approximately 3000 yrs back, the tectonic uplift rate estimated for the area (around $1 \mathrm{~mm} / \mathrm{yr}$ ) was also considered (Lentini and Carbone, 2014). Further, considering the time span, a relative rise of approximately $3 \mathrm{~m}$ in the sea level was simulated. The results of the procedure are shown in Fig.5a.

However, the reconstruction did not consider the sediment supply transported by the Modione River over the centuries and proven to be several meters by the field surveys carried out in the terminal portion of the basin. Further, based on the geomorphological considerations and assessing the current topography, the position of the shoreline was modified and moved further inland (Fig.5b). The latter hypothesis was coincidently similar to that formulated by the archaeologists Hulot and Fougères at the beginning of the XXth century (Hulot and Fougères, 1910) and is described by those authors in Fig.5c.

Additionally, the configuration of the final sectors of the two rivers (Modione and Belice) should be also significantly different compared to that of current period. Today the Modione River (Fig.6a), as well as Belice, appears almost straight with a very narrow section, although the latter shows mild sinuosity (Fig.6b). Field surveys and analysis of the aerial photos provided by the Italian Army Geographic Institute for 1955, 1978, and 2000, however, highlighted the existence of thalwegs which were considerably wider than those of current period and the presence, on both valley sides, of abandoned meanders compatible, with the historical period under discussion, in distance and height with respect to the current valley floor (Fig.7). 

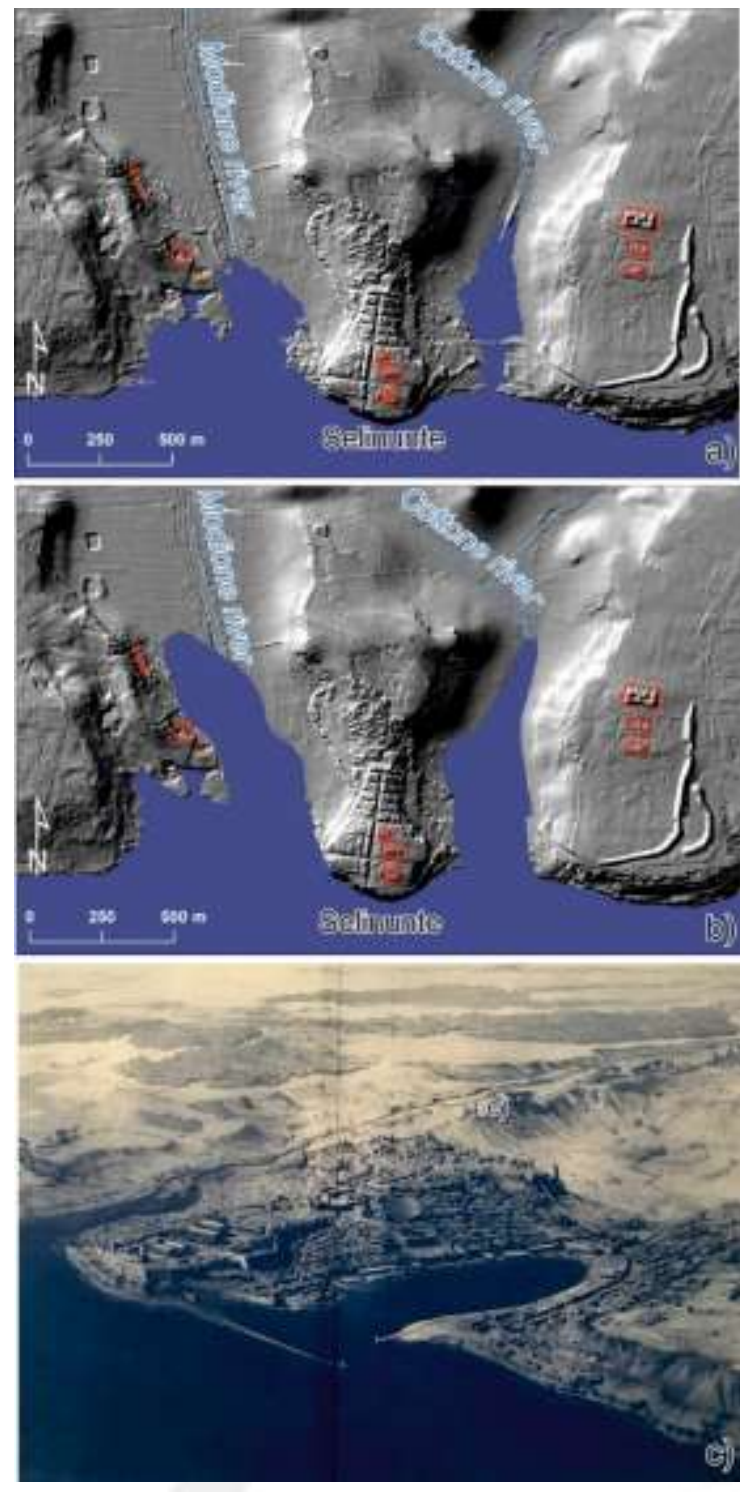

Figure 5 - a) LIDAR image (Digital Elevation Model - DEM) showing the hypothetical shoreline at about 2,700 yrs BP; b) same image subsequently corrected excluding the contribution of sediments by the Modione river; c) reconstruction of the ancient city of Selinunte in Hulot and Fougères, 1910. 


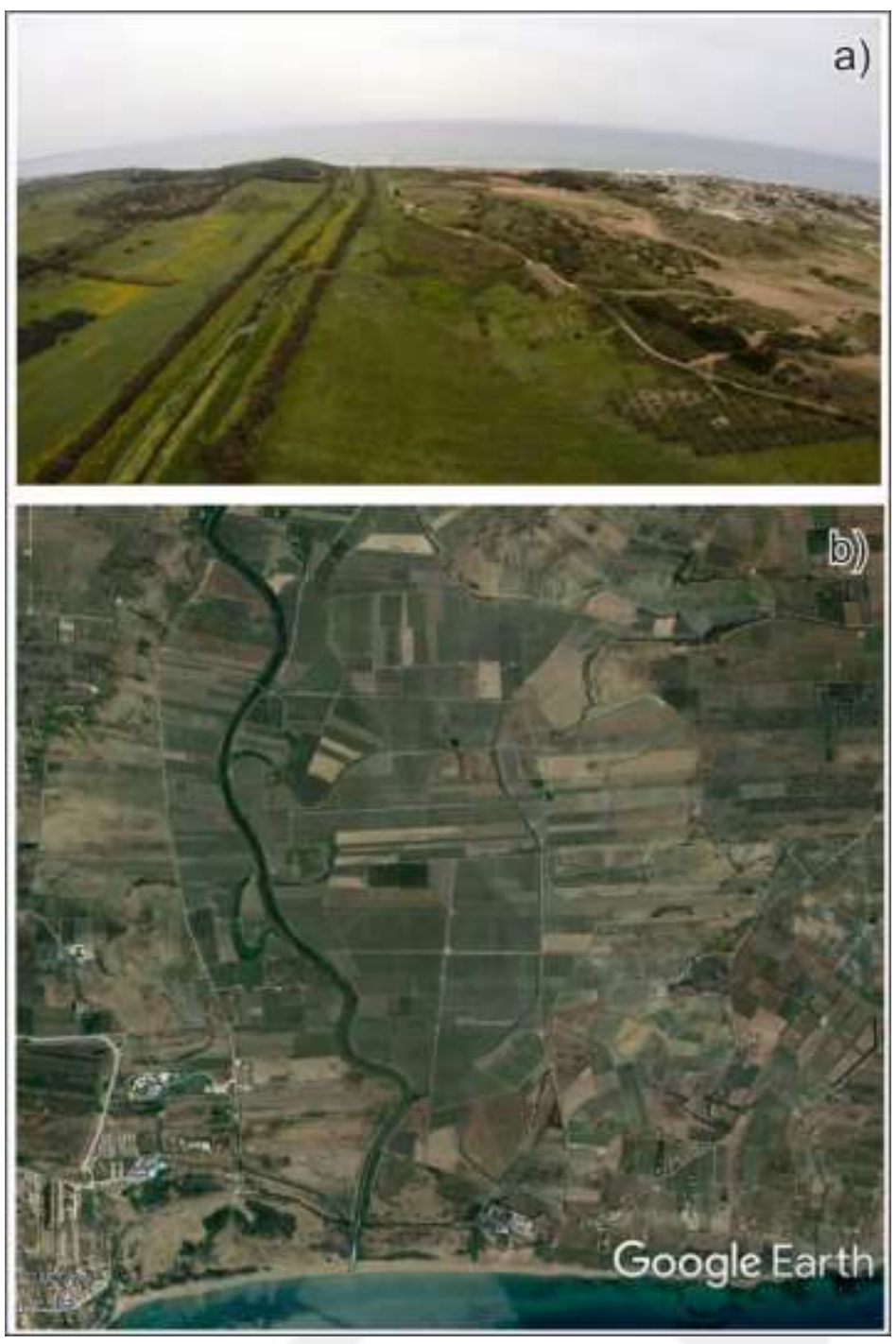

Figure $6-a)$ Aerial view (from north) of the final sector of the Modione river, strongly restricted and rectified by human activities; b) satellite image (Google Earth) of the final sector of the Belice river

Further, the existence of rivers characterized by meandering paths and discharges, likely to be greater than today, would also be compatible with the climatic conditions of the period. The phase between 7000 and 4500 yrs BP, corresponding to the Holocene "climatic optimum", has been in fact, characterized by hot and humid conditions throughout the Mediterranean, with considerable rainfalls noted even near the coastal areas (Noti et al., 2009; Giraudi et al., 2011; Calò et al., 2012). Under these conditions, the rivers could have been navigated with rafts or small boats, even for several kilometers further inside, representing important communication and commercial routes. The Belice river, in particular, whose catchment area extended almost until Palermo to the north (Fig.8), would have constituted a very strategic natural element for the Greek colonists, which were increasingly consolidating their presence in the border territory, consisting of different populations and ethnicities. 


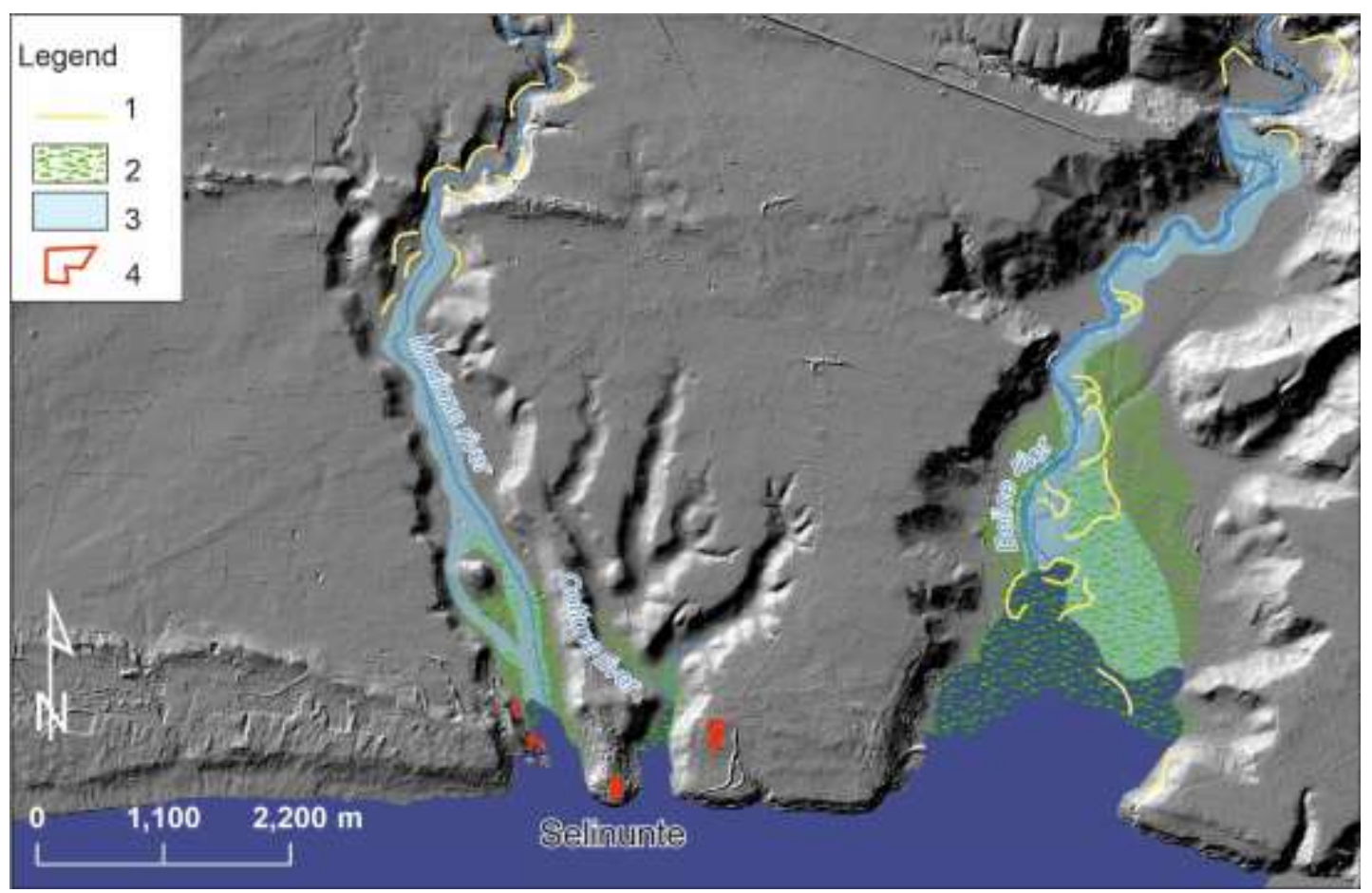

Figure 7 - LIDAR image (DEM) showing the possible configuration of the Modione and Belice rivers at 2,700 yrs. BP: 1-traces of paleo meanders; 2-marshy areas; 3-active fluvial channels; 4-main archaeological sites.

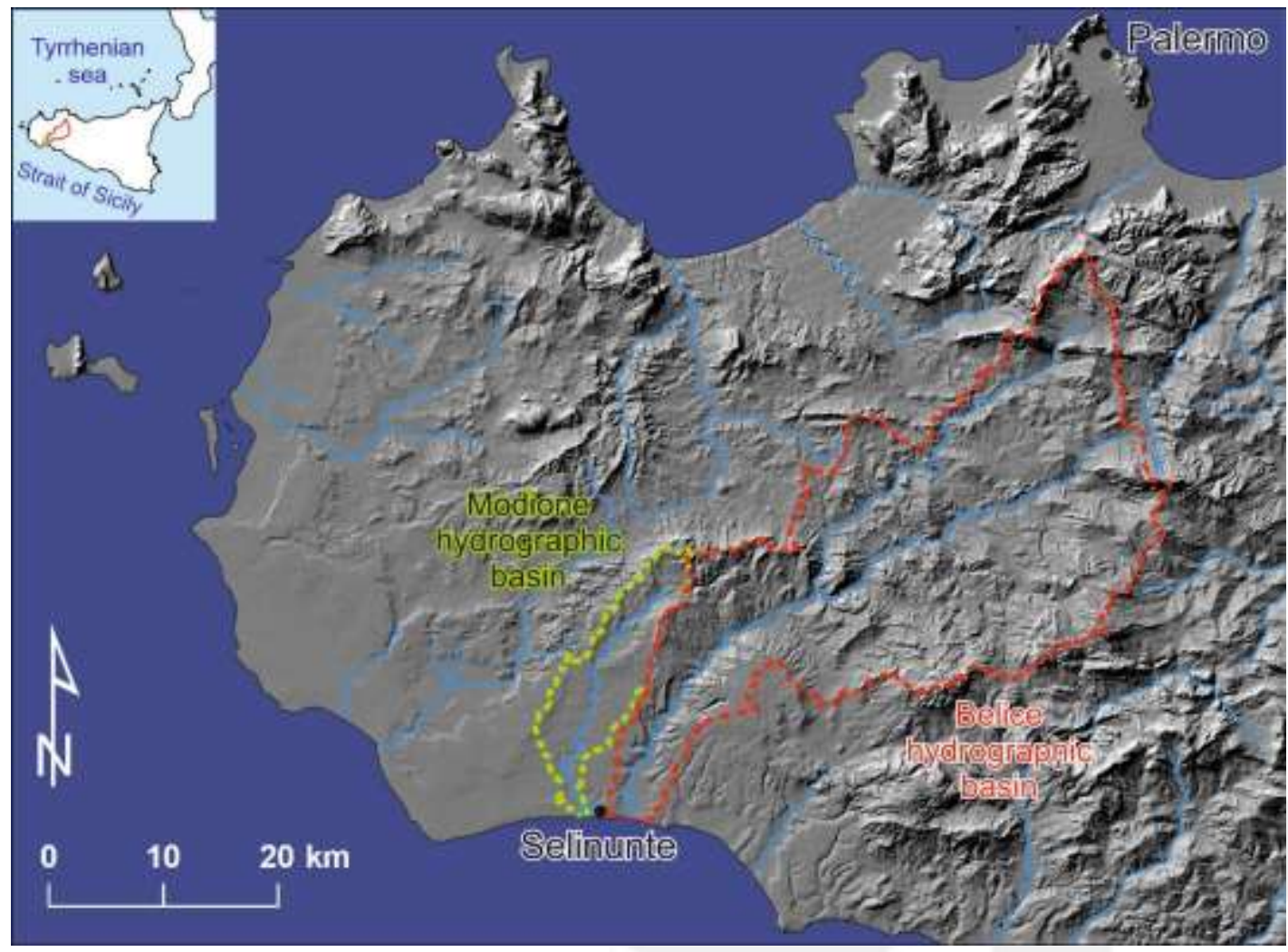

Figure 8 - Digital Elevation Model of western Sicily with reconstruction of the Modione and Belice hydrographic basins 
The navigability of the terminal reach of the Modione River was also confirmed by a stratigraphic survey carried out at approximately $400 \mathrm{~m}$ from its mouth (Fig.9). It can be observed from the figure that at least $25 \mathrm{~m}$ of sediments of probable Holocene age passed from a strictly marine to marshy environment, up to colluvial; this fact testified how the mouth of Modione was originally constituted as an inlet of considerable depth. This configuration, as mentioned by several historical sources, lasted, with similar characteristics, until at least the VIth century BC. (Delano-Smith, 1979, Zazo et al., 2008).

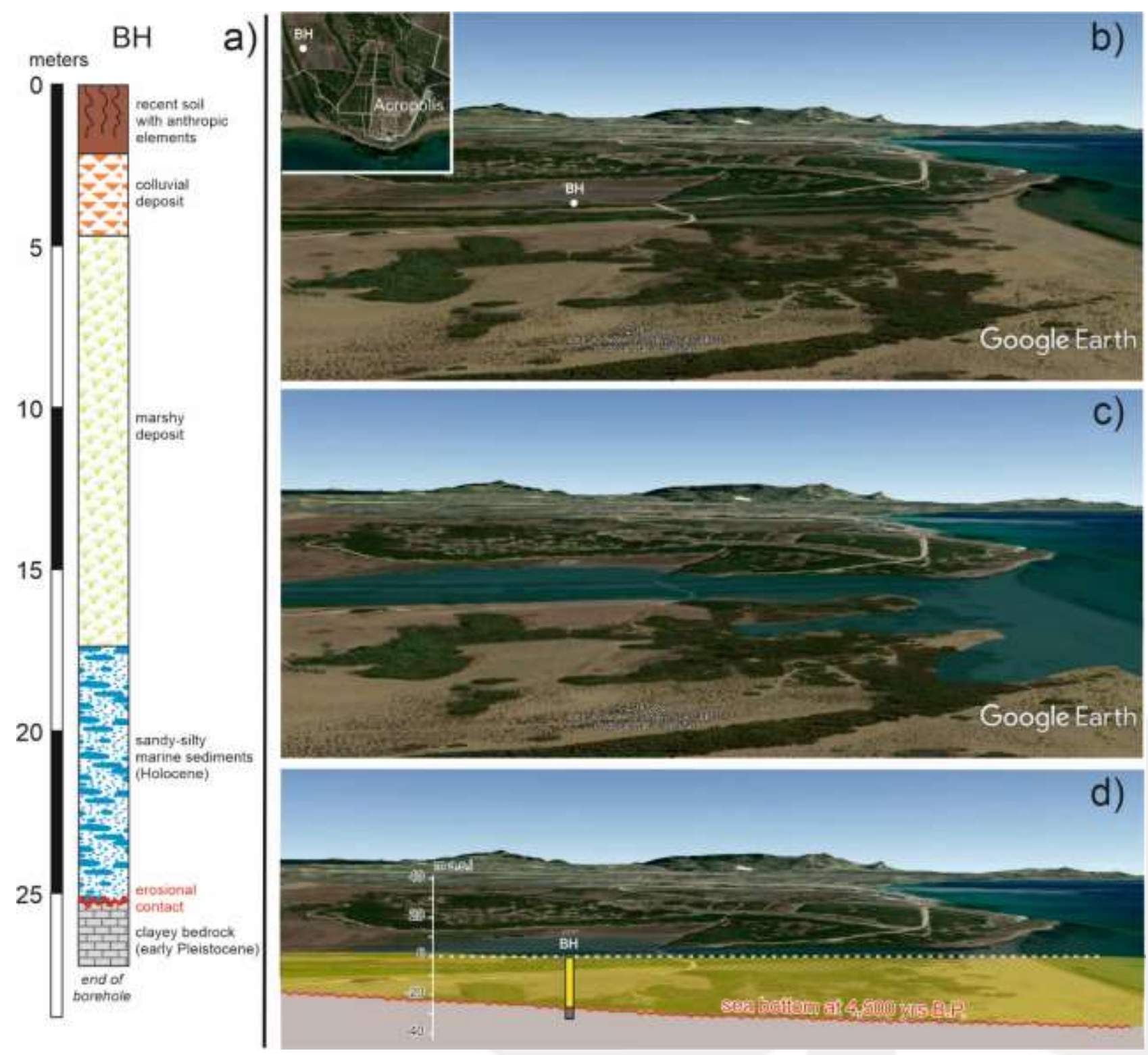

Figure 9 - a) Stratigraphic $\log (\mathrm{BH})$ carried out roughly $400 \mathrm{~m}$ far from the Modione river mouth; b) panoramic view (from $\mathrm{W}$ ) of the final sector of the Modione river valley; $\mathrm{c}$ ) hypothesis of reconstruction of the coastal environment at 2,700 yrs BP; d) sea bottom configuration at around 4,500 yrs BP in correspondence of the Modione river mouth. 
Of great importance for the development of the city, was also the possibility to exploit water resources for drinking, agricultural, or religious purposes in the places of worship.

The current data indicated a condition particularly critical and linked to the scarcity of surface or groundwater resources, common to the entire coastal area of western Sicily. The important deep aquifer, situated in the study area, within the calcarenitic-marly complex of the Marnoso-arenacea Formation of Belice valley, had been heavily depleted, especially after 1980, mainly owing to overexploitation of the well fields located in the Castelvetrano and Campobello di Mazara plain, situated north of Selinunte (Bonanno et al., 2000). The hydrogeomorphological surveys carried out in the terminal portion of the Modione and Gorgo Cottone valleys also highlighted the existence of only small springs and limited wetlands, compatible with a water table just below the surface (Fig.10).
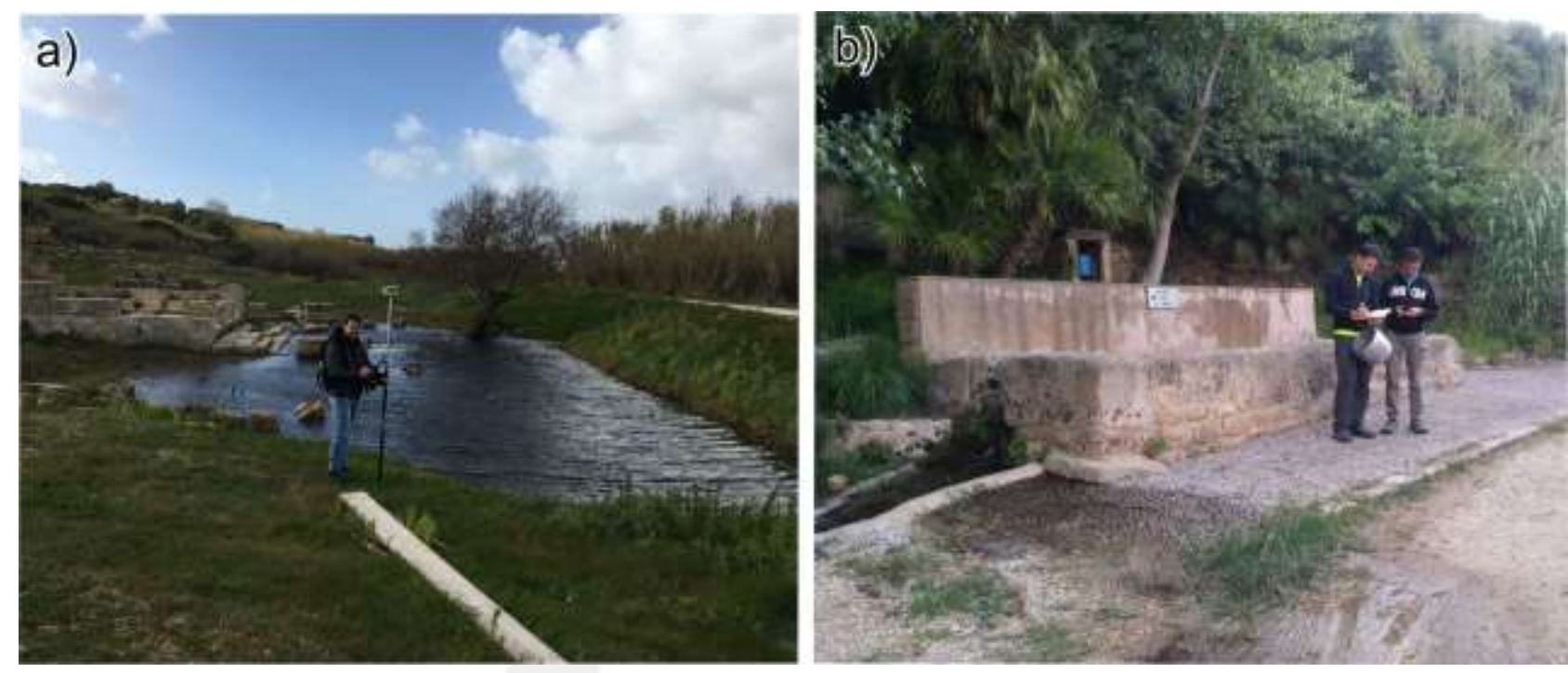

Figure 10 - a) Wet area near the Demetra Malophorous sanctuary, corresponding to the increase of the water table after a rainfall; b) the Gaggera spring, still flowing in the area of the extra-urban sanctuaries.

This context, however, could not explain the strong incisions present immediately north of the Gorgo Cottone, generated in the complete absence of a surface drainage network (Fig.11a). Additionally, they could not justify the high water requirement of such a large city that contrarily, could depend upon numerous springs and wells, the latter generally dug at shallow depths (4-5 m) to exploit water contained within the calcarenitic bank of the acropolis. In the Vth century BC itself, Selinunte was forced to integrate these quantities with water from the Bigini spring, located $14 \mathrm{~km}$ north, at an altitude of $258 \mathrm{~m}$ a.s.l., on the left riverbank of the Modione. Fragments of the aqueduct, built for this purpose, were found in the eastern part of 
the Acropolis. According to historian Cavallari, the aqueduct precisely entered that sector of the city.
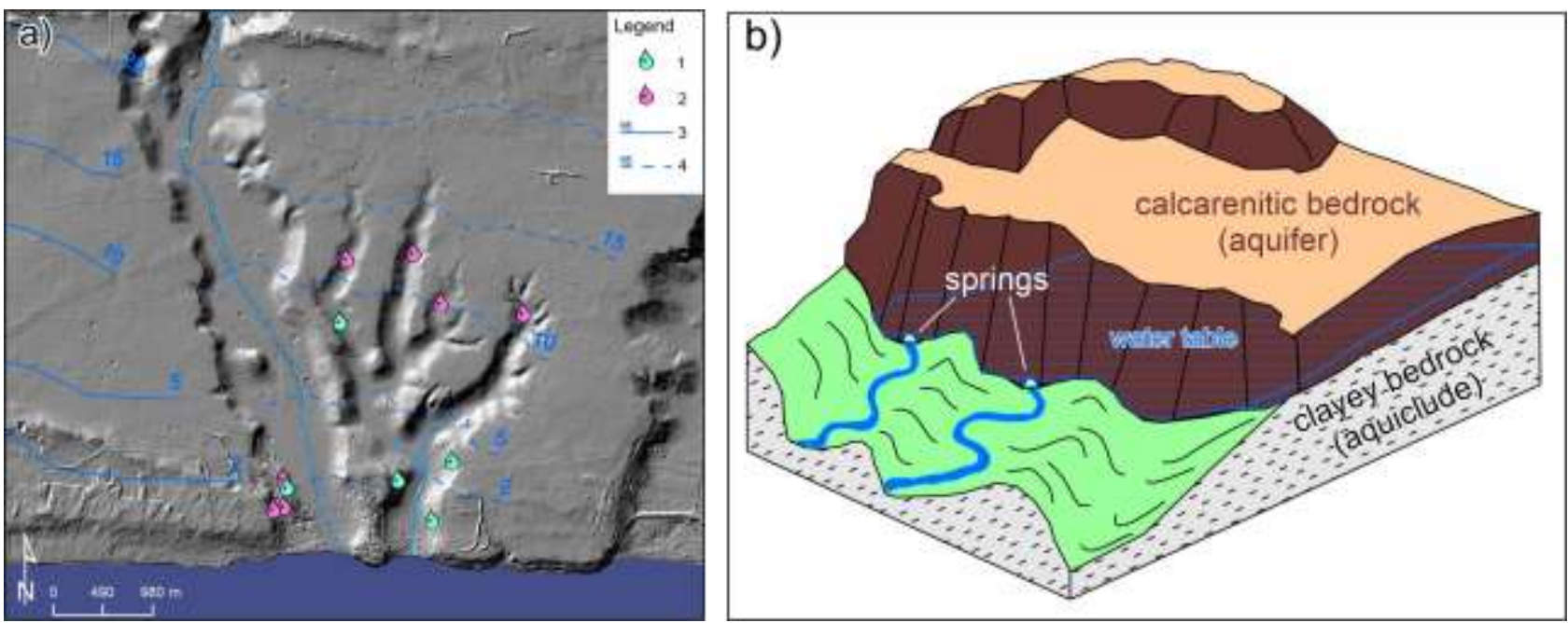

Figure $11-$ a) Hydrogeological sketch of the study area: 1) present day springs; 2) historical springs (hypothesized); 3) isopiezometric lines (modified from Bonanno et al., 2000); 4) isopiezometric lines (reconstructed from field surveys) b) block diagram showing the genesis of natural springs in the study area.

The situation must have been significantly different 3000 yrs ago. The groundwater level, considerably higher than the current level with drainage mainly along SW direction, resulted in important springs, both along the hydrographic right of the Modione River and further east in the Gorgo Cottone area. Similar conditions were evident even more toward the west, where wetlands, home to natural reserves ("Preola lake" and "Gorghi Tondi"), are still present. It is considered that all these water outcomes would be associated, as mentioned, with groundwater circulating within karst systems and daylighting at the contact with the underlying impermeable clayey formations (Fig.11b).

\section{Decline phase (2600-2200 yrs B.P.)}

The particularly favorable socio-environmental context described above began to change drastically from around $2600 \mathrm{yrs} \mathrm{BP}$, due to the concomitance of climatic and anthropic factors. With regard to the climatic factors, rapid transition happened towards arid-cold climatic conditions, characterized by scarce rainfall and significant increase in wind activity along the coastal belt (Goudie et al., 1993; Calò et al., 2012). Yet, its consequences on the landscape (which had already started, albeit with a lower intensity, around $4500 \mathrm{yrs}$ BP throughout the Mediterranean basin), occurred after a time lag of 150-200 years, the period necessary for the 
activation and completion of typical fluvial-coastal and slope processes. Analysis of the aerial photos and field surveys have enabled us to recognize the morphologies and thicknesses of the sediments associated with the rapid phenomena of aggradation of the river valleys and mouths as well as intense wind activity, with the formation of dunes, even at considerable distances from the coast (Fig.12). The dating of these processes can be indirectly deduced from historical sources, which mention the difficulties of navigating the terminal reaches of the rivers and the formation of marshy areas, with the consequent spread of epidemic diseases.

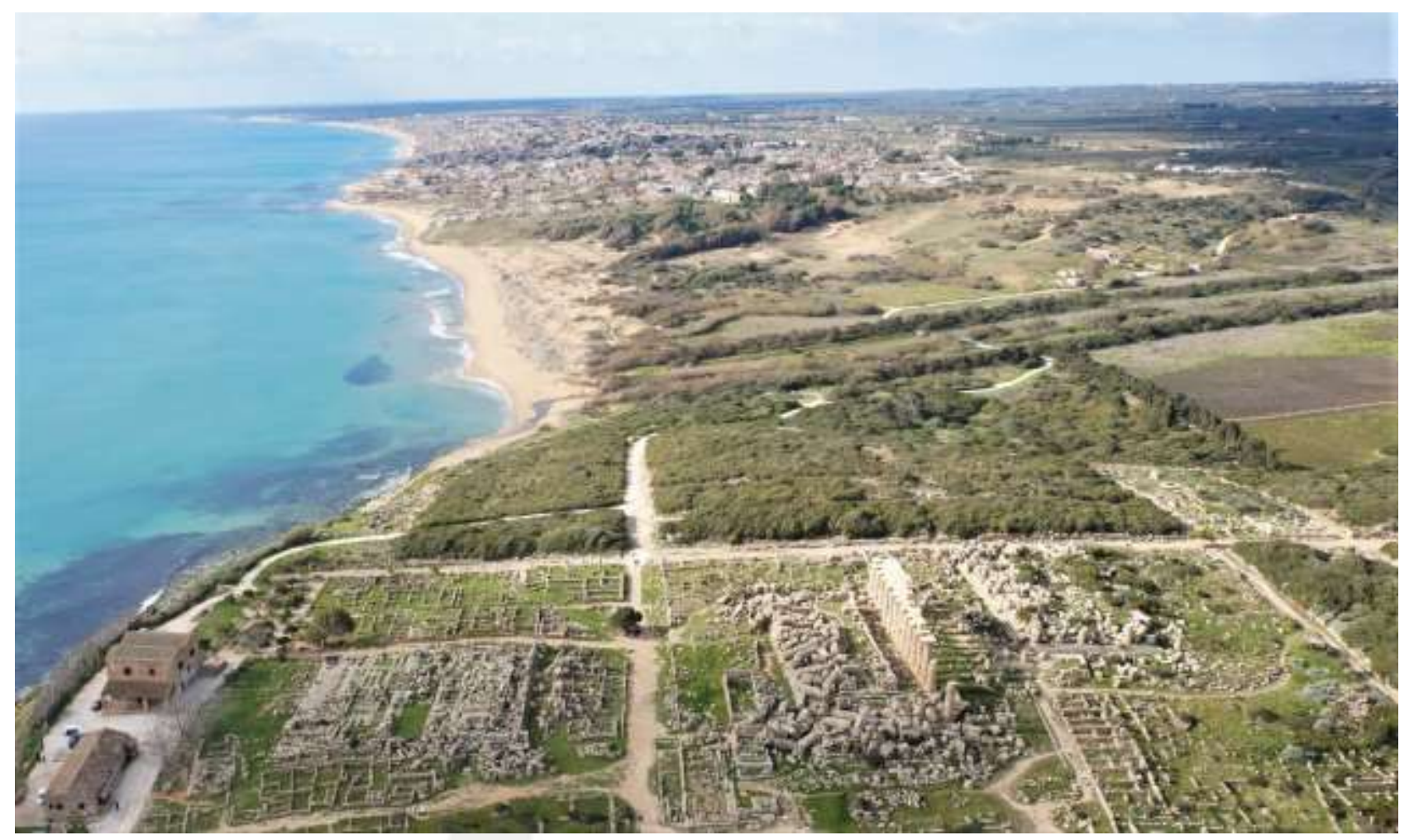

Figure 12 - Aerial view (taken by drone) of the Modione river mouth; very evident is the presence of sandy dunes up to hundreds of meters far from the shoreline

The geomorphological processes described were also amplified due the anthropic occupation of the site. Paleobotanical and archaeobotanical studies carried out in SW Sicily (Calò et al., 2012) showed that the entire forests of evergreen trees, extensively present in the coastal area around 7000 yrs BP, remained mostly intact up to about $2600 \mathrm{yrs}$ BP, when they underwent a rapid decline until they were completely disappeared.

This decline was marginally related to climate change, while the development of agricultural practices for the production of cereals and use of wood for heating and civil uses contributed mostly towards it (De Angelis, 2000). The sharp reduction in vegetation along the slopes amplified the erosion and, consequently, sediments accumulation and transportation 
within the riverbeds. Surface and groundwater resources also underwent sharp decrease. The construction of aqueducts (such as that of Morgantina, dated around $2600 \mathrm{yrs}$ BP and that of Bigini described above) necessary to meet the agricultural and civil needs of a growing population, resulted in significant and irreversible lowering of the water table (Crouch, 1984; Calò et al., 2012).

The culmination of this "environmental crisis" is documented to have occurred around $444 \mathrm{BC}$, when, as mentioned in chapter 3, the city of Selinunte asked Empedocles to resolve the problem of epidemics that continuously occurred due to the presence of swampy areas. However, despite historical sources, no trace or remainder of this famous intervention has been found until date.

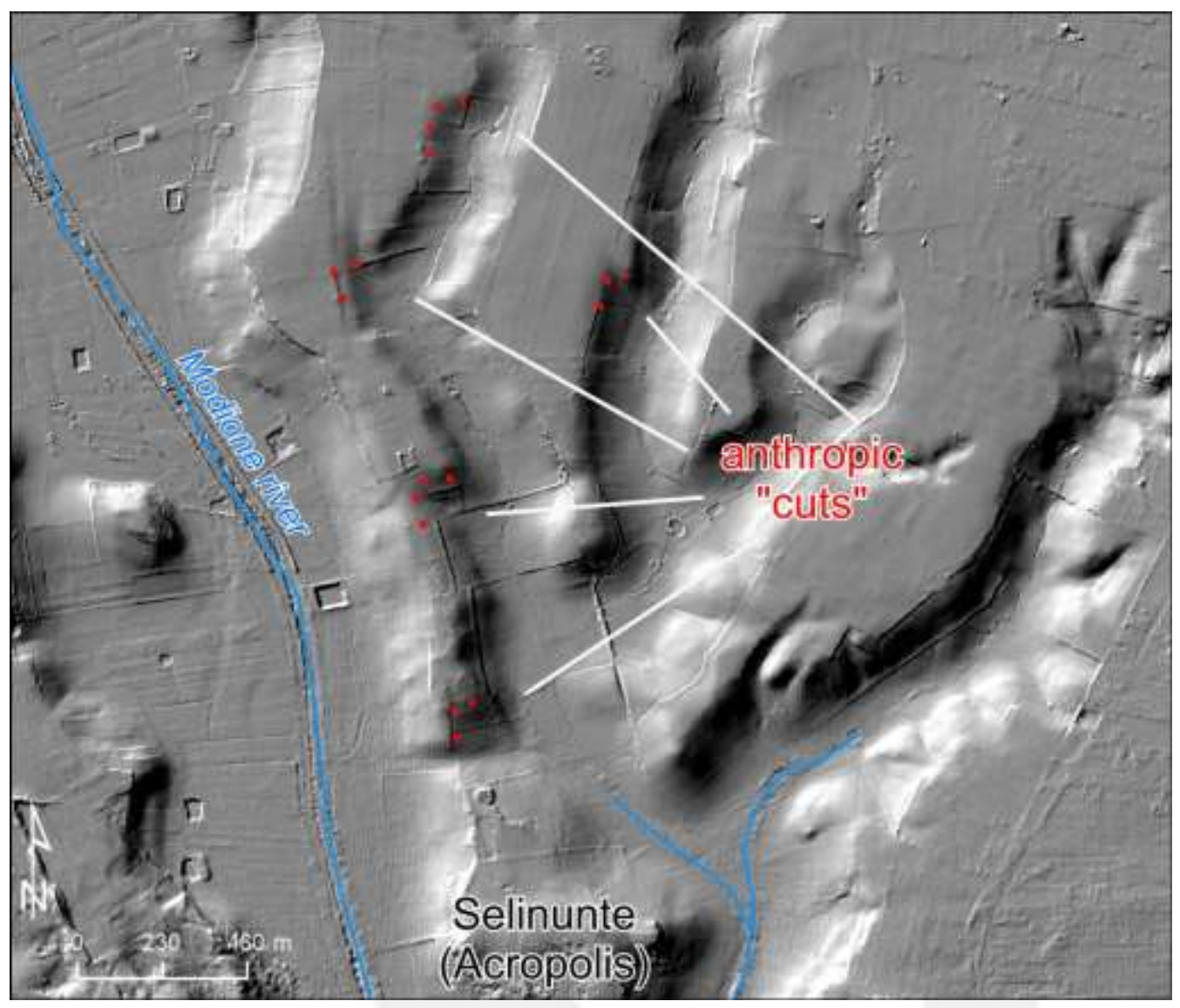

Figure 13 - Lidar image (DEM) showing the traces of artificial "cuts" along two main reaches of the Gorgo Cottone basin.

Field surveys, geophysical prospections and interpretation of aerial photos carried out using drones within the Gorgo Cottone basin, highlighted the presence of cuts and deviations in the drainage network, especially in the westernmost sector, which were clearly indicative of anthropic origin, (Fig.13). These modifications, not associated with any recent human 
intervention and not described in any historical source, could correspond to the works that aimed to "capture" and regulate groundwater which, as mentioned in the paragraph 4.1.1, daylighted in the upper part of the basin. These emergencies can still be found in correspondence with some of these "cuts", although with a limited discharge due to climate change and, most importantly, overexploitation that occurred at the end of the XXth century. These regulated waters could also feed the aqueduct of the city, the remnants of which were found in the area, as mentioned earlier.

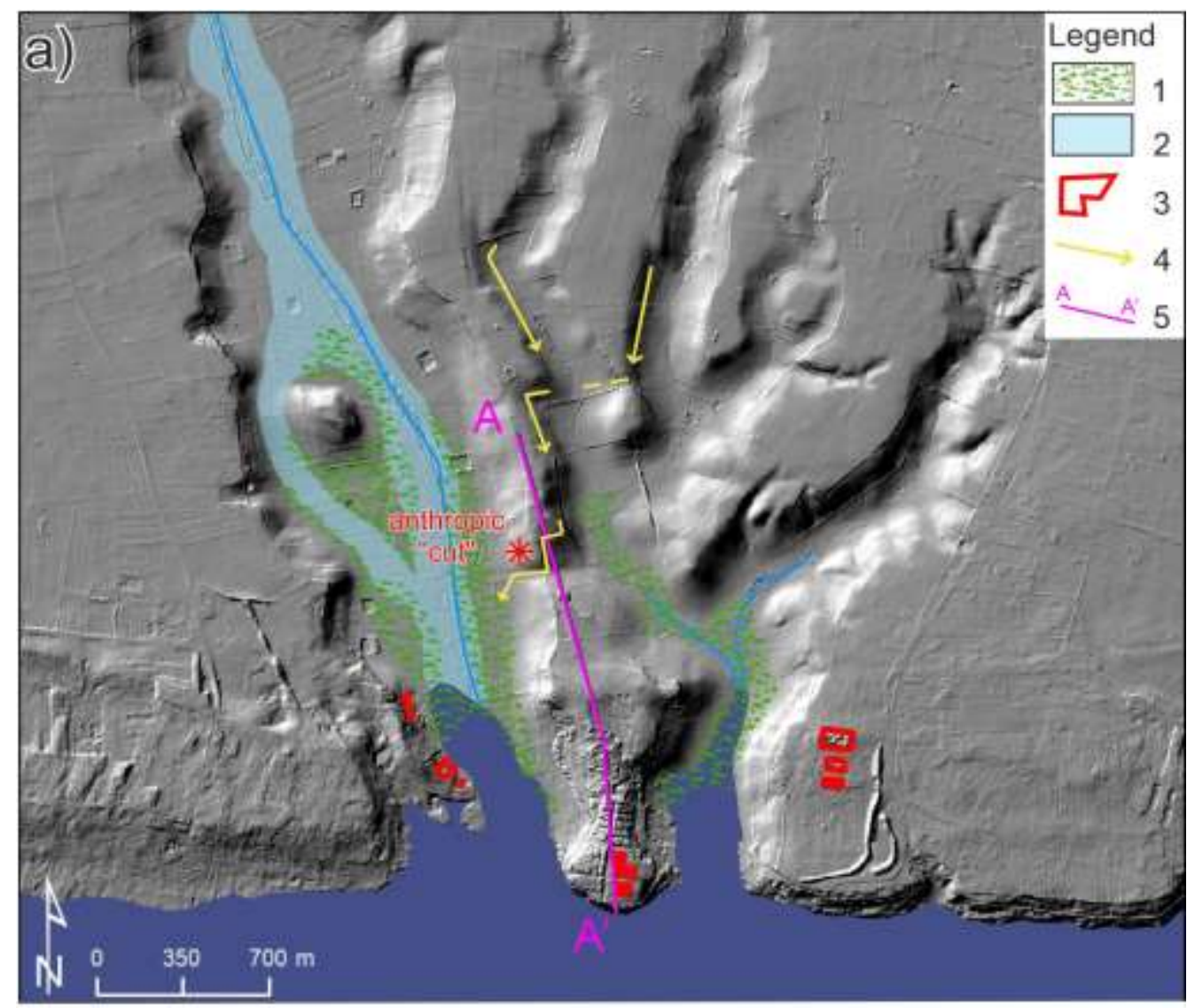

b)
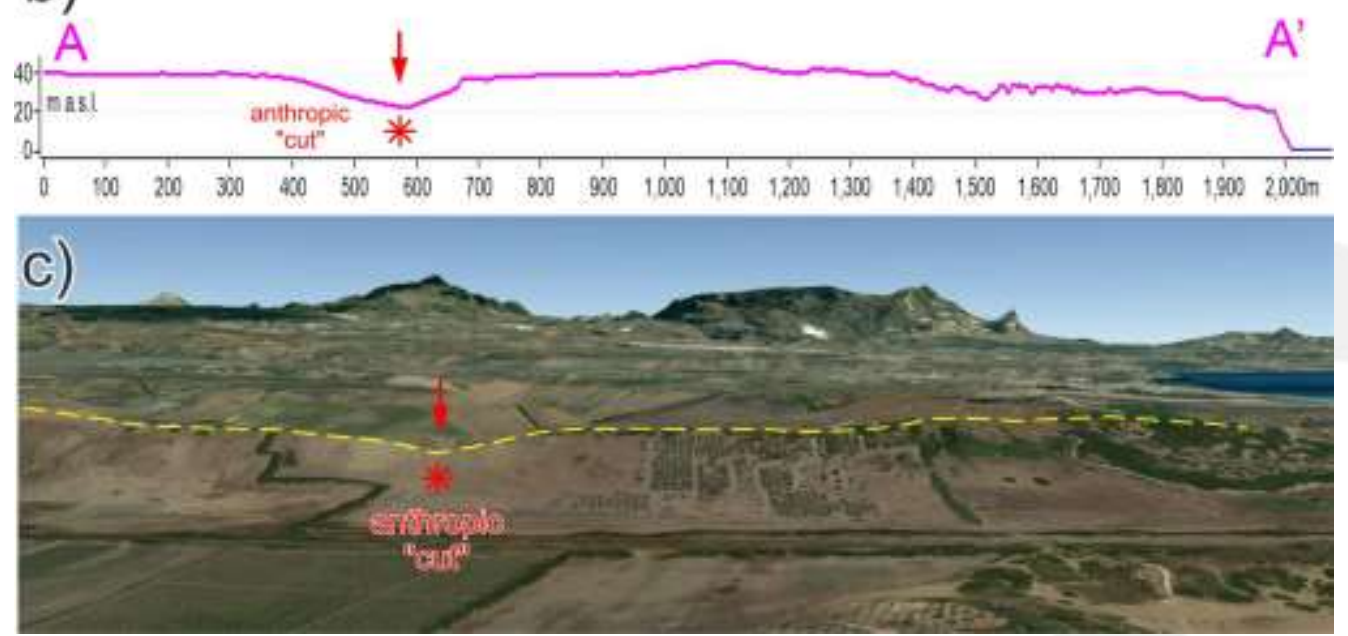
Figure 14 - The "Empedocles intervention". a) Hypothesis of location and type of intervention; 1marshy areas; 2-active fluvial channels; 3-main archaeological sites; 4-drainages direction; 5-trace of cross-section; b) topographic cross-section along the top of the calcarenite plate; c) 3D image (modified from Google earth) showing the hypothetic location of the anthropic "cut".

Using this context, the famous intervention of Empedocles could be possibly located. By examining the aerial image and most importantly, the topographic profile, shown in Fig.14, a clear interruption was observed in the continuity of the calcarenitic bank that outcrops in the area of the agora and Acropolis. Considering the geological and geomorphological setting, this discontinuity, similar to a highly incised saddle (15-20 m deep from the top of the calcarenitic bank), could neither be linked to lithological changes (selective erosion) nor to the gravitational phenomena or the tectonic elements (faults). By excluding these causes, the only possible hypothesis remained of a somewhat anthropogenic trench. More specifically, it could correspond to a grand drainage work, which would have transferred water of the Gorgo Cottone to the terminal portion of the Modione basin collected through the cuts previously described (Fig.14a).

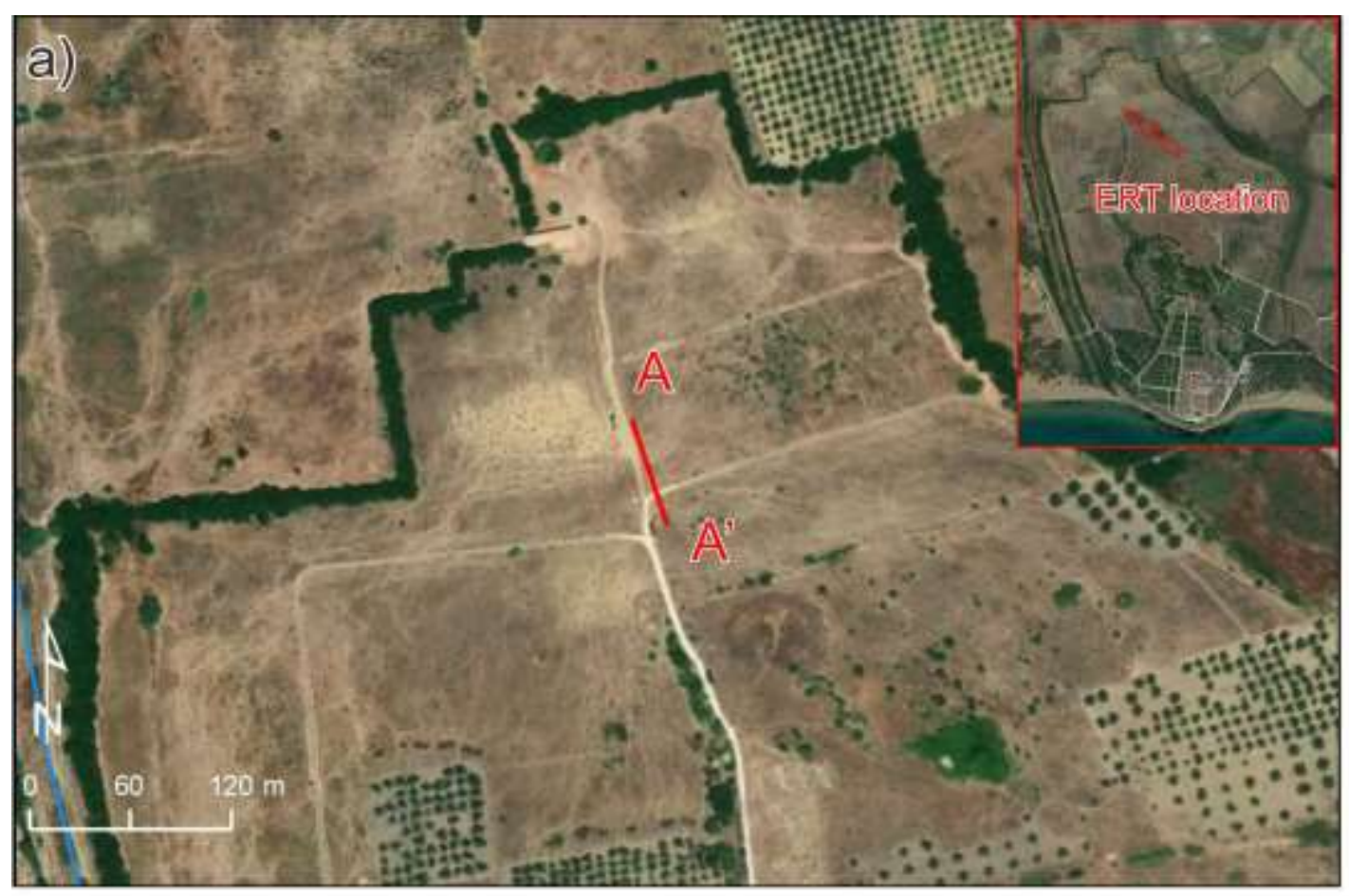

b)

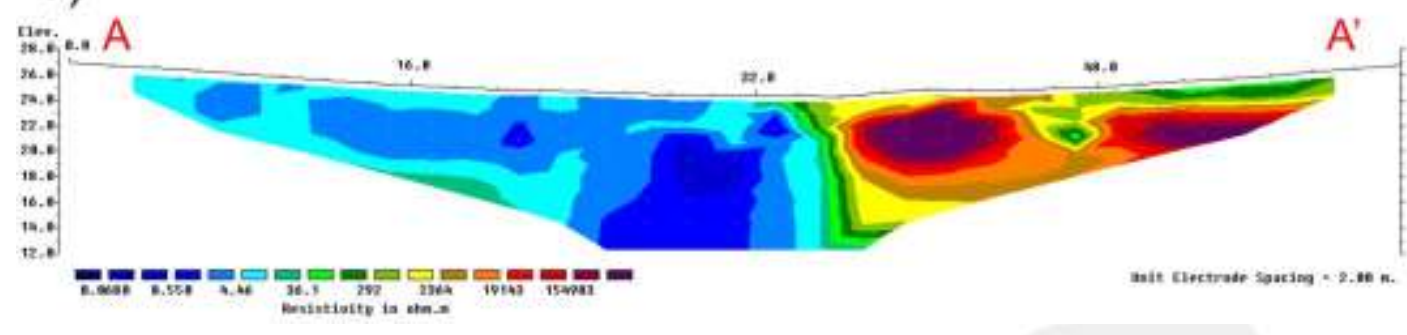


Figure 15-2D Electrical Resistivity Tomography (ERT) carried out north of the agora. a) Location of the array; $b$ ) observed apparent resistivity pseudosection.

The anthropic origin of the saddle, or at least its remodeling starting from a natural morphology, was also confirmed by electric tomography, whose trace and interpretation are reported in Fig.15a and b. The equipment used was a PASI instrument, equipped with 32 electrodes ( $2 \mathrm{~m}$ spacing). Measurements were carried out using Wenner-Schlumberger arrays to preserve an appropriate compromise between the vertical and horizontal shapes of the retrieved anomalies (Loke, 2012). For inverting the apparent resistivity data, an algorithm based on the deconvolution method of least minimum squares was used (software RES2DINV v.3.59), which enabled the acquisition of 2D sections through finite elements calculation modules, also accounting for the topography.

As seen in Fig.15b, the sharp change in resistivity between 34 and 38 m, testified that the passage between areas characterized by more conductive soils (probably sandy-silty colluvial deposits) with calcarenitic bedrock (significantly resistive, probably due to the presence of voids and fractures), was cut vertically along a well-defined and geometric surface. This morphology did not reflect the lithostratigraphic structure of the area and could hardly be traced back only to the natural erosion processes. The hypothesis of an anthropogenic cut appeared more likely.

From a chronological point of view as well, the hypothesis will sustain, considering that the anthropic occupation of the site reached its peak in the aforementioned period and no testimonies exist of such important interventions, both in the previous periods and in subsequent historical phases.

More problematic, however, is the reconstruction of the exact type of intervention that likely intercepted the waters of one or more rivers and reached an altitude to allow the difference between the two basins to be overcome with a trench or a small valley. However, due to the lack of anthropic structures that can corroborate the above-mentioned theory, further investigations have been planned in the field and, most importantly, geophysical campaign (electric tomography and georadar investigations) will be carried out inside the saddle to verify the existence of buried anthropic structures.

The intervention of Empedocles, which supposedly ended the epidemics, however, was not able to restrain the overall process of environmental "degradation" which had already started around 2600-2500 yrs BP, due to climatic and, most importantly, anthropic factors. The concomitance of the war events in the following periods and the progressive loss of 
"georesources," such as soil, vegetation, and, mostly, groundwaters, created the conditions for the rapid decline of the civilization of Selinunte and for the future abandonment of the site.

\section{Conclusion}

In this study, a multidisciplinary approach and different investigation techniques (direct and indirect) demonstrated that modern archaeological research should acquire comprehensive knowledge about the environmental conditions within which various civilizations were developed. Specifically, examining the availability of georesources and, most importantly, reconstructing the paleoclimate, the paleomorphologies and the ancient geomorphological processes, have been increasingly considered to have contributed in establishing and developing a city or a site, or resulting in its decline.

This study, conducted at Selinunte, enabled to accurately define the relationship between man and the environment during the colonization period and, in particular, testify the following conclusions:

- Existence of favorable morphological and climatic conditions that enabled the development of a thriving city, suitable for trade. In addition, the presence of two natural gulfs helped in establishing commercial and military ports.

- Presence of navigable rivers enabled the exchange of goods between internal areas and the coast;

- Availability of basic georesources, such as water, used for both civil and religious purposes as well as building materials, obtained from the calcarenitic banks and used for both houses and temples.

Similarly, the subsequent phase of the decline of the city, occurred in conjunction with an "environmental crisis" and partly accentuated by important anthropic landscape modifications, resulted in:

- Substantial decrease in water resources, which was also due to overexploitation of wells and springs, which necessitated the works for the collection and drainage of water.

- Increase in the erosion processes on the slopes, with subsequent transport of sediments along the riverbeds and at the mouths. This was due to a climatic shift towards arid conditions and deforestation, due to timber extraction and expansion of areas suitable for agriculture. The main consequence was the progressive loss of navigability conditions of the rivers and formation of marshy areas along the river mouths, which also created the conditions for spreading diseases and epidemics. 
The war that happened in the city in last two centuries, therefore, took place under different environmental conditions, which although not sufficiently explored by historians, certainly influenced and conditioned its course.

\section{Disclosure statement}

No potential conflict of interest was reported by the authors

\section{References}

Antonioli, F., Cremona, G., Immordino, F., Puglisi, C., Romagnoli, C., Silenzi, S., Valpreda, E., Verrubbi, V., 2002 - New data on the Holocenic sea-level rise in NW Sicily (Central Mediterranean Sea). Global and Planetary Change 34, 121-140.

Bice, K.L., Norris, R.D. 2002 - Possible atmospheric CO2 extremes of the Middle Cretaceous (late Albian-Turonian). Paleoceanography, 17. doi:10.1029/2002PA000778.

Bonaccorso, B., Bordi, I., Cancelliere, A., Rossi, G., Sutera, A. 2003 - Spatial Variability of Drought: An Analysis of the SPI in Sicily. Water Resources Management 17, 273-296.

Bonanno A., Ciabatti P., Liguori V., Provenzano M.C., Sortino G. 2000 - Studio idrogeologico ed idrogeochimico dell'acquifero multifalda della Piana di Castelvetrano e Campobello di Mazara (Sicilia occidentale). Quaderni di Geologia Applicata, 7, 4, 45-59.

Bottari C., Aringoli D., Carluccio R., Castellano C., D’ajello Caracciolo F., Gasperini M., Materazzi M., Nicolosi I., Pambianchi G., Pieruccini P., Sepe V., Urbini S., Varazi F. 2017 Geomorphological and geophysical investigations for the characterization of the roman Carsulae site (Tiber Basin, Central Italy). Journal of Applied Geophysics, vol. 143, p. 74-85, ISSN: 0926-9851, doi: 10.1016/j.jappgeo.2017.03.021.

Brooks, N. 2006 - Cultural responses to aridity in the Middle Holocene and increased social complexity. Quaternary International, 151, 29-49.

Brooks, N. 2010 - Human responses to climatically-driven landscape change and resource scarcity: Learning from the past and planning for the future. In I.P. Martini \& W. Chesworth (Eds.), Landscapes and societies: Selected cases (pp. 43-66). London, Dordrecht: Springer, Heidelberg.

Brooks N., 2012 - Beyond collapse: climate change and causality during the Middle Holocene Climatic Transition, 6400-5000 years before present. Geografisk Tidsskrift-Danish Journal of Geography, 112, 2, 93pp.

Burke, M.B., Miguel, E., Satyanath, S., Dykema, J.A., Lobell, D.B. 2009 - Warming increases the risk of civil war in Africa. Proceedings of the National Academy of Sciences, 106, 20670 20674.

Calò, C., Henne, P.D., Curry, B., Magny, M., Vescovi, E., La Mantia, T., Pasta, S., Vanniere, B., Tinner, W., 2012 - Spatio-temporal patterns of Holocene environmental change in southern Sicily. Palaeogeogr. Palaeoclimatol. Palaeoecol. 323-325, 110-122.

Chen, Z., Wang, Z., Schneiderman, J., Tao, J., Cai, Y. 2005 - Holocene climate fluctuations in the Yangtze delta of eastern China and the Neolithic response. The Holocene, 15, 915-924.

Crouch, D.P., 1984 - The Hellenistic water system of Morgantina (Sicily): contributions to the history of urbanization. American Journal of Archeology 88, 353-365.

Cullen, H.M., deMenocal, P.B., Hemming, S., Hemming, G., Brown, F.H., Guilderson, T., Sirocko, F. 2000 - Climate change and the collapse of the Akkadian empire: Evidence from the deep sea. Area, 4, 379-382. 
D’Angelo, U., Vernuccio, S. 1994 - Note illustrative della Carta Geologica del Foglio 617 "Marsala" (scala 1:50.000). Boll. Soc. Geol. It., CXIII, 55-67.

D’Angelo, U., Vernuccio, S. 1996 - I terrazzi quaternari della estremità occidentale della Sicilia, Mem. Soc. Geol. It., 51, 585-596.

Delano-Smith C. 1979 - Western Mediterrean Europe. Academic Press, London, 453pp.

DeMenocal, P.B. 2001 - Cultural responses to climate change during the late Holocene Science, 292, 667-673.

di Lernia, S. 2002 - Dry climatic events and cultural trajectories: Adjusting Middle Holocene pastoral economy of the Libyan Sahara. In F.A. Hassan (Ed.), Droughts, food and culture: Ecological change and food security in Africa's Later Prehistory (pp. 225-250). New York, NY: Kluwer.

Di Maggio C., Madonia G., Vattano, M., Agnesi, V., Monteleone, S. 2017 - Geomorphological evolution of western Sicily, Italy. Geologica Carpathica, 68, 1, 80-93. doi: 10.1515/geoca2017-0007.

Giraudi, C., Magny, M., Zanchetta, G., Drysdale, R.N. 2011 - The Holocene climatic evolution of Mediterranean Italy: A review of the continental geological data. The Holocene 21, 1, $105-$ 115. doi: 10.1177/0959683610377529.

Goudie, A.S., Viles, A.H., Pentecost, A. 1993 - The late-Holocene tufa decline in Europe. The Holocene, 3, 2, 181-186. doi: 10.1177/095968369300300211.

Haywood, A., Williams, M. 2005 - The climate of the future: Clues from three million years ago. Geology Today, 21, 138-143.

Huber, B.T. 1998 - Tropical paradise at the cretaceous poles? Science, 282, 2199-2200.

Hulot, J., Fougères, G. 1910 - Sélinonte. Colonie dorienne en Sicile. La Ville, l'Acropole et les Temples. Relevés et restaurations par Jean Hulot. Texte par Gustave Fougères. Paris, Librairie générale de l'architecture et des arts décoratifs, Ch. Massin Éditeur, 1910.

Jónsson, G. 2010 - The environmental factor in migration dynamics - a review of African case studies. Paper No. 21. International Migration Institute, James Martin 21st Century School, University of Oxford.

Lamb, H.H. 1995 - Climate, history and the modern world. Routledge, London, 410pp.

Lambeck, K., Antonioli, F., Anzidei, M., Ferranti, L., Leoni, G., Scicchitano, G., Silenzi, S. 2011 - Sea level change along the Italian coast during the Holocene and projections for the future. Quaternary International 232, 250-257.

Lambeck, K., Antonioli F., Purcell, A., Silenzi, S. 2004 - Sea-Level change along the Italian coast for the past 10.000 yrs, Quaternary Science Reviews 23, 1567-1598

Lentini, F., Carbone, S. 2014 - Geology of Sicily. Mem. Descr. Carta Geol. d'It. XCV, 7-414. Liuzzo, L., Bono, E., Sammartano, V., Freni, G. 2017 - Long-term temperature changes in Sicily, Southern Italy. Atmospheric Research 198, 44-55. doi.org/10.1016/j.atmosres.2017.08.007.

Loke, M.H. 2012 - Tutorial: 2-D and 3-D Electrical Imaging Surveys. Geotomo Software, Malaysia.

Myers, N. 2002 - Environmental refugees: A growing phenomenon of the 21st century. Philosophical Transactions of the Royal Society of London B, 357, 609-613.

Noti, R., van Leeuwen, J.F.N., Colombaroli, D., Vescovi, E., Pasta, S., La Mantia, T., Tinner, W., 2009. Mid- and late-Holocene vegetation and fire history at Biviere di Gela, a coastal lake in Southern Sicily, Italy. Veg. Hist. Archaeobot. 18 (5), 371-387.

Ruggieri, G., Unti, A., Unti, M., Moroni, A. 1977 - La calcarenite di Marsala (Pleistocene inferiore) e i terreni contermini. Boll. Soc. Geol. It., 94, 1623-1657.

Stanley, J.D., Krom, M.D., Cliff, R.A., Woodward, J.C. 2003 - Short contribution: Nile flow failure at the end of the Old Kingdom, Egypt: Strontium isotopic and petrologic evidence. Geoarchaeology, 18, 395-402. 
Suhrke, A. 1993 - Pressure points: Environmental degradation, migration and conflict. Occasional Paper No. 3, Project on Environmental Change and Acute Conflict. American Academy of Arts and Sciences and the University of Toronto, Cambridge, MA.

Vita-Finzi C. 1969 - The Mediterranean valleys. Geological changes in historical times. Cambridge University Press, 133pp.

Weiss, H., Bradley, R.S. 2001 - What drives societal collapse? Science, 291, 609-610.

Wenxiang, W., Tungsheng, L. 2004 - Possible role of the "Holocene Event 3" on the collapse of Neolithic Cultures around the Central Plain of China. Quaternary International, 117(1), 153166.

Zazo, C., Dabrio, C.J., Goy, J.L., Lario, J., Cabero, A., Silva, P.G., Bardajı, T., Mercier N., Borja, F., Roquero E., 2008 - The coastal archives of the last $15 \mathrm{ka}$ in the AtlanticMediterranean Spanish linkage area: Sea level and climate changes. Quaternary International, $181,72-87$ 